\title{
ROLE OF SHODHANA ON ANTIMICROBIAL ACTIVITY OF TUTTHA
}

\author{
Research Article
}

\section{Anita Mahapatra $^{1}$, Brahmananda Mahapatra ${ }^{2}$}

1. Research Scientist, AVP Research Foundation, Coimbatore

2. Prinicpal, Govt Ayurveda College, Bolangir, Odisha

\begin{abstract}
Tuttha is one among the Maharasas, well known and frequently used mineral in Rasaaushadis. Ayurveda classical texts indicate to use in skin diseases, ulcer, sinus, worm infection, vitiligo, obesity, pain, asthma, hyper acidity, hemorrhoids, diseases of eyes and as Krimighna etc. But advocates only after specific procedures called Shodhana (purification procedures) before making any pharmaceutical form since crude Tuttha causes vomiting and giddiness etc. The present antimicrobial study was carried out on two Tuttha named crude Tuttha and Shodhita Tuttha before and after Shodhana. Antibacterial activity on Escherichia coli, Bacillus subtilis, Salmonella typhi, Staphylococcus aureus bacterias and antifungal activity on fungi Candida albicans and Trichophyton rubrum were carried out by agar disk diffusion method. The shodhana process results that Shodhita Tuttha was found to be more effective compared to crude, as the diameter of the zone of inhibition was higher, even at low concentration of $1 \mathrm{mg}$. The present study shows the importance of Shodhana process by enhancing the antimicroabial activity.
\end{abstract}

Keywords: Tuttha, Agar disk diffusion method, Antifungal, Antibacterial, Ayurveda

\section{Introduction}

Tuttha is a mineral and chemically copper sulphate(1), that has been indicated in various diseases from skin diseases(2) to eye diseases(3) etc. Reviews of classical texts of Ayurveda suggest to use more in the form of external use than internal use. Caraka samhita is the texts of general medicines suggest to use mainly in external dosage form. Later by other masters of Ayurveda suggested use as orally. Tuttha is mentioned by Ayurvedic classic as Katu (pungent), Kshara (alkali),

\footnotetext{
*Corresponding Author:

Anita Mahapatra,

Research Scientist,

AVP Research Foundation,

Coimbatore, Tamil Nadu.

E-mail: dranitads@gmail.com
}

Kashaya (astringent), Laghu (light to digest), Vamaka (emetic), Lekhana (scraping), Bhedana (penetrating), Usna (hot) in potency, Cakshushya (good for eyes), pacifies Kaphapitta (4) and Krimighna (antimicrobial).(5)

The Ayurvedic Pharmacopoeia of India, suggests Tuttha shall not be used in formualtions without subjecting it to Shodhana.(6) The crude of Tuttha causes vomiting and giddiness etc.(7) Rasashastra advocates only after specific procedures called shodhana (purification procedures) by different medias like triturated with lemon juice(8)/rakta varga(9) [Rakta Varga consists of following Kusumbha (Carthemus tincterius), Khadira (Acacia catechu), Laksa (Laccifera lacca), Manjishta (Rubia cardifolia), Rakta candana (Pteroceupus santalinus) Aksi, 
Bandhujiva (Pentapetis phoenicea) Karpugandhini and Honey] and then sneha varga(10) [Sneha Varga consists of Ghee, (Seasame) oil, Animal fat \& fat from the bone marrow cavity]/ boiled in cows', goats', buffalows' urine(11), which have their own significance in detoxifying and increasing the therapeutic potential of minerals. Since a comparative microbial activity was not available, this study was conducted to know the role of Shodhana on their antimicrobial activity.

\section{Materials and methods}

Tuttha was collected from local market and matched with grahya lakshanas (qualities as described in the classics), viz., Snigdha (unctuous), Guru (heavy), Mahaujjala (very bright blue in color) were observed and selected the sample for the study. The qualitative estimation of copper and sulpur was done by A.A.S. (Atomic absorption spectroscopy)(12) revealed that crude Tuttha contains copper - $23.78 \%$, Sulphur - $11.98 \%$, Iron - $0.33 \%$ and undetectable sodium.

Tuttha was subjected Shodhana as per classical text mentioned in the text Rasa Tarangini.(13) 750gms of Tuttha was taken in a mortar and pestle and $350 \mathrm{ml}$ of Lemon juice (Citrus acida Roxb.) was poured to make it sufficiently wet. Then with pestle trituration was done with pressure for 6 hours; then allowed the paste to dry and then collected. There was a loss of $10 \mathrm{gms}$ of Tuttha after purification. After purification of Tuttha with Lemon juice, quantitative chemical analysis done by A.A.S. (Atomic absorption spectroscopy), the copper content was increased to $26.74 \%$, iron content was increased to $0.76 \%$ and sulphur content was decreased to $8.46 \%$.

The crude and Shodhita sample of Tuttha were subjected to anitmicrobial study by agar disk diffusion method.

\section{Antimicrobial study Organisms}

Antibacterial study on grampositive organisms used in the study were Staphylococcus aureus, Bacillus subtilis and gram-negative organism were Salmonella typhi and Escherichia coli. The fungi Candida albicans and Trichophyton rubrum were used in the study.

\section{Preparation of test/stock solution}

Suspension of crude and Shodhita

Tuttha were prepared by dissolution of test sample - at $1 \mathrm{mg} / \mathrm{ml}$, the bhasma was vortexed in distilled water and loaded as such taking into consideration the particulate nature of the salt and its usage.

\section{Preparation of agar plates}

The Petri dishes which measured around $32 \mathrm{~cm}$ diameter and $2 \mathrm{~cm}$ thickness were selected after sterilizing by dry heat in an oven. Base layer was obtained by pouring around 20-30 $\mathrm{ml}$ of Muller Hinton Agar solution to obtain a thickness of 4 $\mathrm{mm}$. It was then kept for solidification. The overnight grown subculture from the mother culture (procured from T- Stanes laboratory, Coimbatore) was taken in definite volumes of peptone water and incubated at $37^{\circ} \mathrm{C}$ at least for $2-4$ hours prior to plating. After incubation with the help of cotton swab, the organisms were streaked on Petri dish containing base layer medium.(14) Following this, the cylinders are placed from a height of approximately $1 / 8$ inch onto the agar surface as an alternate to well as per diffusion method. The cylinders on each plate are filled with the test sample. After the cylinders are filled, the plates are carefully placed in the $37^{\circ} \mathrm{C}$ in incubator where they remain for 15 to 16 hours. The diameter of each circle of inhibition is measured to the nearest $0.25 \mathrm{~mm}$.

Readings the test samples are averaged, unless it is obvious that a cylinder has been jarred or that it leaks badly.(Zones around such cylinders are 
often abnormally large or not perfectly circular.) (15)

The antimicrobial activity is expressed as zone diameter in millimeters, which is measured by a scale.

\section{Results}

The drug concentration in each microliter of test solution was as $1 \mathrm{mg}$, $5 \mathrm{mg}, 10 \mathrm{mg}$ and $20 \mathrm{mg}$. The zone of inhibition for Tuttha samples were measured by a scale and the measurements are tabulated. [Table No. 1]

The zone of inhibition images are shown in plates from image number 1 to 10. [Image No. 1 to 12]

\section{Discussion}

Copper sulaphate exothermically dissolves in water to give the aquo complex $[\mathrm{Cu}(\mathrm{H} 2 \mathrm{O}) 6] 2+$, which has octahedral molecular geometry and is paramagnetic. It is uses as a herbicide, fungicide and pesticide. During the process of Shodhana, copper sulaphate triturated with lemon juice it converts to copper citrate. The bright blue colour in crude form converts to a green or bluish green crystalline powder after purification. Tuttha sample was studied on Escherichia coli, Bacillus subtilis, Salmonella typhi Staphylococcus aureus, Escherichia coli, Candida albicans and Trichophyton rubrum.

The samples were assessed by agar method, by comparing zone of inhibition between test samples. In low concentraion, it was found that Shodhita Tuttha found is a better antifungal than antibacterial agent. Shodhita Tuttha was found to be more effective compared to crude, as the diameter of the zone of inhibition was higher, even at low concentration of $1 \mathrm{mg}$. It is bactericide to Escherichia coli, Bacillus subtilis, Staphylococcus aureus, Salmonella typhi and fungicide to Trichophyton rubrum and Candida albicans. Crude Tuttha was alone bactericidal to Salmonella typhi.
In high concentration, it was found that both samples have comaparable zone of inhibition for both antifungal than antibacterial activity. Both samples have shown better showed better antibacterial result against Bacillus subtilis compared to other organisms and showed better antifungal result in Trichophyton rubrum against Candida albicans.

The comparative zone of inhibition towards microbial organisms in lowest and highest concentration of Crude and Shodhita Tuttha are show below in graphs number 1 and 2. [Graph No. - 1 and 2]

\section{Conclusion}

The cultures were sensitive to the test samples above $1 \mathrm{mg}$, hence the concentration was increased to $5 \mathrm{mg}$, $10 \mathrm{mg}, 20 \mathrm{mg}$. No zone of inhibition was observed at concentration below $1 \mathrm{mg}$ (i.e. (a) $100 \mu \mathrm{g}, 500 \mu \mathrm{g})$. Shodhita Tuttha was found to be more effective compared to crude, as the diameter of the zone of inhibition was higher, even at low concentration of $1 \mathrm{mg}$. The present study shows that Shodhana procedure enhanced the antimicrobial activity in Shodhita Tuttha compared to crude Tuttha.

\section{Acknowledgement}

The authors wish to thank Dr.K.Latha, Project Director, T-Stanes and company Limited, Coimbatore for her sincere guidance in this antimicrobial study.

\section{Reference}

1. Tuttha. The Ayurvedic pharmacopoeia of India, part-1, vol -7. 1st edition. New Delhi:Govt of India;2009.p.45.

2. Charaka Samhita, Agnivesh, Ayurveda Dipika Sanskrit commentary, Vaidya Jadavaji Trikamji Acharya, Sutra Sthana, Navegadharaniya adhyaya (7:102), P.455, Munshiram Manoharlal Publishers Pvt.Ltd, New Delhi, 1992.

3. Charaka Samhita, Agnivesh, Ayurveda Dipika Sanskrit commentary, Vaidya 
Jadavaji Trikamji Acharya, Sutra Sthana, Trimarmiyacikitsa adhyaya (26:250), P.611, Munshiram Manoharlal Publishers Pvt.Ltd, New Delhi, 1992.

4. Acharya JT, editor. Rasamritam. Varanasi: Chaukhambha Sanskrit Bhawan; 1998. p. 58.

5. Sadanand Sharma. Rasatarangini, XI edition. Varanasi: Motilal Banarasidas; 1979. p. 543.

6. Tuttha. The Ayurvedic pharmacopoeia of India, part-1, vol -7. 1st edition. New Delhi: Govt of India;2009.p.46.

7. C.B.Zha. Ayurvedia Rasashastra, Chaukhambha Surbharti Prakashan; 2003. p. 232.

8. Sadanand Sharma. Rasatarangini, XI edition. Varanasi: Motilal Banarasidas; 1979. p. 540.

9. Ray P C, Kaviratna H C, editor. Rasarnava. Calcutta: The Asiatic Socity; 1985. p. 105.
10. Dole. Rasaratnasamuccaya, 2nd edition. Varanasi: Chowkhamba Sanskrit Series Office; 2008. p. 73.

11. Dole. Rasaratnasamuccaya, 2nd edition. Varanasi: Chowkhamba Sanskrit Series Office; 2008. p. 73.

12. Chemical analysis of Rock/Ore samples by Instrumental methods. The Ayurvedic pharmacopoeia of India, part-1, vol -7. 1st edition. New Delhi:Govt of India;2009.p.80.

13. Sadanand Sharma. Rasatarangini, XI edition. Varanasi: Motilal Banarasidas; 1979. p. 540.

14. Howard BJ. Clinical and Pathogenic microbiology. Toronto: CVM Company; 2 nd ed. 1987. p. 914-5.

15. Schmidt and Moyer, A.J,1944 Penicillin, I. mehtods of assay, J. Bacteriol., 47:199.

Table 1: Zone of inhibition measured in $\mathrm{mm}$ of Crude Tuttha and Shodhita Tuttha in different concentrations

\begin{tabular}{|l|c|c|c|c|c|c|c|c|}
\hline $\begin{array}{c}\text { Sample / } \\
\text { Organism }\end{array}$ & \multicolumn{2}{|c|}{$\mathbf{1}$ mg conc. } & \multicolumn{2}{|c|}{$\mathbf{5}$ mg cocnc. } & \multicolumn{2}{|c|}{$\mathbf{1 0}$ mg conc. } & \multicolumn{2}{|c|}{$\mathbf{2 0 ~ m g ~ c o n c . ~}$} \\
\cline { 2 - 8 } & $\begin{array}{c}\text { Crud } \\
\text { e } \\
\text { Tutth } \\
\text { a }\end{array}$ & $\begin{array}{c}\text { Shodhit } \\
\text { a Tuttha }\end{array}$ & $\begin{array}{c}\text { Crude } \\
\text { Tuttha }\end{array}$ & $\begin{array}{c}\text { Shodhi } \\
\text { ta } \\
\text { Tuttha }\end{array}$ & $\begin{array}{c}\text { Crude } \\
\text { Tuttha }\end{array}$ & $\begin{array}{c}\text { Shodhi } \\
\text { ta } \\
\text { Tuttha }\end{array}$ & $\begin{array}{c}\text { Shodhi } \\
\text { Crude } \\
\text { Tuttha } \\
\text { Tuttha }\end{array}$ \\
\hline E.coli & - & $9 \mathrm{~mm}$ & $15 \mathrm{~mm}$ & $19 \mathrm{~mm}$ & $20 \mathrm{~mm}$ & $25 \mathrm{~mm}$ & $24 \mathrm{~mm}$ & $26 \mathrm{~mm}$ \\
\hline B. subtilis & - & $5 \mathrm{~mm}$ & $29 \mathrm{~mm}$ & $28 \mathrm{~mm}$ & $29 \mathrm{~mm}$ & $30 \mathrm{~mm}$ & $28 \mathrm{~mm}$ & $30 \mathrm{~mm}$ \\
\hline S.typhi & $6 \mathrm{~mm}$ & $7 \mathrm{~mm}$ & $15 \mathrm{~mm}$ & $14 \mathrm{~mm}$ & $19 \mathrm{~mm}$ & $18 \mathrm{~mm}$ & $24 \mathrm{~mm}$ & $24 \mathrm{~mm}$ \\
\hline S.aureus & - & $5 \mathrm{~mm}$ & $19 \mathrm{~mm}$ & $16 \mathrm{~mm}$ & $24 \mathrm{~mm}$ & $22 \mathrm{~mm}$ & $28 \mathrm{~mm}$ & $24 \mathrm{~mm}$ \\
\hline C.albicans & - & $12 \mathrm{~mm}$ & $16 \mathrm{~mm}$ & $14 \mathrm{~mm}$ & $19 \mathrm{~mm}$ & $20 \mathrm{~mm}$ & $24 \mathrm{~mm}$ & $26 \mathrm{~mm}$ \\
\hline T. rubrum & - & $10 \mathrm{~mm}$ & $19 \mathrm{~mm}$ & $12 \mathrm{~mm}$ & $21 \mathrm{~mm}$ & $20 \mathrm{~mm}$ & $24 \mathrm{~mm}$ & $20 \mathrm{~mm}$ \\
\hline
\end{tabular}


Graph No.1. Shows zone of inhibition (in $\mathrm{mm}$ ) of Tuttha samples in Low concentration

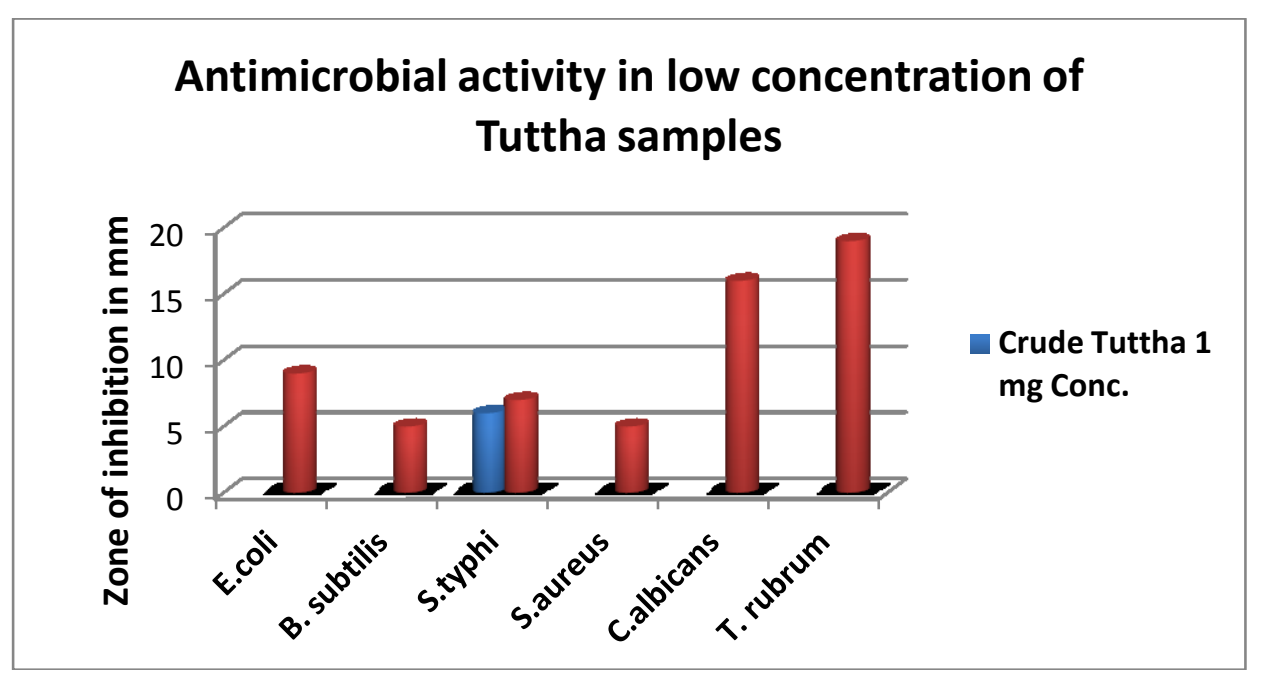

Graph No.2. Shows zone of inhibition (in $\mathrm{mm}$ ) of Tuttha samples in High concentration

Antimicrobial activity in high concentration of Tuttha samples

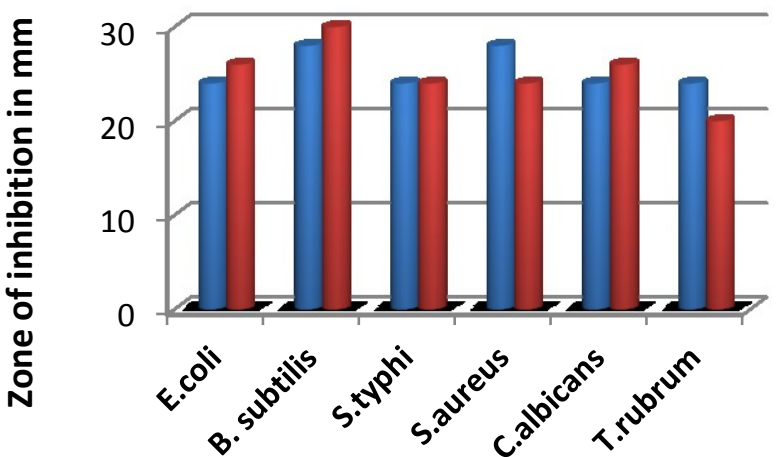

Crude Tuttha $20 \mathrm{mg}$ Conc. 
Images from No. 1 to 12








$* * * * *$ 